\title{
Keratinolytic activities of alkaliphilic Bacillus sp. MBRL 575 from a novel habitat, limestone deposit site in Manipur, India
}

\author{
Pintubala Kshetri and Debananda S. Ningthoujam*
}

*Correspondence:
debananda.ningthoujam@
gmail.com
Microbial Biotechnology
Research Laboratory,
Department of Biochemistry,
Manipur University,
Canchipur 795003, India

*Correspondence: debananda.ningthoujam@ Manipur University, Canchipur 795003, India

\begin{abstract}
Microbial degradation of keratinous wastes is preferred over physicochemical methods as the latter is costlier and not eco-friendly. Novel habitats are promising for discovery of new microbial strains. Towards discovery of novel keratinolytic bacteria, screening of bacterial strains from a novel limestone habitat in Hundung, Manipur, India was done and a promising isolate, $\mathbf{M B R L} \mathbf{5 7 5}$, was found to degrade native chicken feather efficiently. It could grow over a broad pH range (Langeveld et al. in J Infect Dis 188:17821789, 2003; Park and Son in Microbiol Res 164:478-485, 2009; Zaghloul et al. in Biodegradation 22:111-128, 2011; Takami et al. in Biosci Biotechnol Biochem 56:1667-1669, 1992; Riffel et al. in J Biotechnol 128:693-703, 2007; Wang et al. in Bioresour Technol 99:5679-5686, 2008) and in presence of 0-15\% NaCl. Based on phenotypic characterization and $16 \mathrm{~S}$ rRNA gene sequence analysis, the new keratinolytic limestone isolate was identified as Bacillus sp. MBRL 575. It produced $305 \pm 12 \mathrm{U} / \mathrm{ml}$ keratinase and liberated $120 \pm 5.5 \mathrm{mg}$ of soluble peptides and $158 \pm 4 \mathrm{mg}$ of amino acids per gram of feather after $48 \mathrm{~h}$ of incubation at $30^{\circ} \mathrm{C}$ in chicken feather medium. The strain could also degrade feathers of other species besides chicken. The cell-free enzyme was also able to degrade feather. Citrate and soybean meal were found to be the best carbon and nitrogen supplements for enhanced enzyme, soluble peptide and amino acid production. In addition to keratinolytic activity, MBRL 575 also exhibited antagonistic activity against two major rice fungal pathogens, Rhizoctonia oryzae-sativae (65\%) and Rhizoctonia solani (58\%).
\end{abstract}

Keywords: Feather-degrading, Keratinase, Alkaliphilic, Hundung, Bacillus

\section{Background}

Keratin is the most abundant protein in epithelial cells and forms major components of skin, hair, nail, feather and wool. Keratins are grouped into hard keratins, found in appendages such as feather, hair, hoof and nail and soft keratins found in callus and skin. The former have high disulfide bond content and are tough and inextensible whereas soft keratins such as skin and callus have low content of disulfide bridges and are more pliable (Gupta and Ramnani 2006). 90 \% of feather weight is constituted by keratin and feathers are produced in large amounts as waste byproducts of poultry processing plants. Several million tons of feather wastes are produced annually worldwide and such wastes could lead to environmental problems (Xu et al. 2009; Sangali and Brandelli 2000; 
Jayalakshmi et al. 2012). Feathers are highly recalcitrant to digestion by common proteolytic enzymes such as trypsin, pepsin and papain (Gradisar et al. 2005). The mechanical stability of keratin depends on the tight packaging of proteins in $\alpha$-helix ( $\alpha$-keratin) or $\beta$-sheet ( $\beta$-keratin) structures and their high degree of cross linkages. Feathers which are hydrolyzed by mechanical or chemical treatment can be converted to animal feed, fertilizer, amino acids, glues and foils. This process not only consumes energy but also degrades some essential amino acids (Cao et al. 2009). Because of these drawbacks, the use of keratinolytic enzymes in the production of amino acids and peptides is becoming attractive for biotechnological applications. Keratinases also find applications in detergent, cosmetic, pharmaceutical, and leather industries. Keratinases capable of degrading prion $\left(\mathrm{PrP}^{\mathrm{sc}}\right)$, infectious protein agent causing 'Mad Cow disease' in animals, have been reported (Langeveld et al. 2003). So far, keratinases have been reported from species of Bacillus (Park and Son 2009; Zaghloul et al. 2011; Takami et al. 1992), Chryseobacterium (Riffel et al. 2007; Wang et al. 2008), Fervidobacterium (Friedrich and Antranikian 1996; Nam et al. 2002), Kocuria (Vidal et al. 2000; Bernal et al. 2006), Lysobacter (Allpress et al. 2002) Microbacterium (Thys and Brandelli 2006), Nesterenkonia (Bakhtiar et al. 2002), Pseudomonas (Sharma and Gupta 2010; Tork et al. 2010), Stenotrophomonas (Cao et al. 2009; Fang et al. 2013), Streptomyces (Bockel et al. 1995; Cheng et al. 2010; Letourneau et al. 1998; Chitte et al. 1999), Vibrio (Xu et al. 2009; Grazziotin et al. 2007), and Xanthomonas (Jeong et al. 2010a). However, only a few strains or enzymes have reached commercial exploitation. Keratinases from Bacillus spp., particularly B.licheniformis and B.subtilis, have been extensively studied (Gupta and Ramnani 2006). In this paper, we report the isolation and characterization of an efficient chicken feather degrading Gram positive, endospore forming, alkaliphilic Bacillus sp. MBRL 575 which also exhibits antagonistic activity against Rhizoctonia spp.

\section{Materials and methods}

\section{Isolation of the bacterial strains}

The soil samples collected from limestone quarry at Hundung, Manipur, India $\left(25.05^{\circ} \mathrm{N}\right.$, $94.33^{\circ} \mathrm{E}$ ) were dried and crushed by mortar and pestle. $1 \mathrm{~g}$ soil sample was dissolved in $100 \mathrm{ml}$ sterile distilled water and kept incubated in a shaker $\left(25^{\circ} \mathrm{C}, 150 \mathrm{rpm}, 30 \mathrm{~min}\right)$. The soil suspension was serially diluted $\left(10^{-3}-10^{-7}\right)$ and $0.1 \mathrm{ml}$ diluted soil suspension was spread plated on Horikoshi Medium 1 (Horikoshi 2004) and the plates were kept incubated at $30^{\circ} \mathrm{C}$ for a week. Morphologically distinct bacterial colonies were selected and subcultured till pure cultures were obtained. The purified cultures were preserved as slants at $4{ }^{\circ} \mathrm{C}$ and as glycerol stocks $(20 \%, \mathrm{v} / \mathrm{v})$ at $-20{ }^{\circ} \mathrm{C}$. Bacterial strains were screened for feather degradation in chicken feather medium (CFM) containing feather, $1 \%(\mathrm{w} / \mathrm{v})$; $\mathrm{KH}_{2} \mathrm{PO}_{4}, 0.5 \%(\mathrm{w} / \mathrm{v}) ; \mathrm{MgSO}_{4}, 0.05 \%(\mathrm{w} / \mathrm{v})$ and $\mathrm{Na}_{2} \mathrm{CO}_{3}, 0.5 \%(\mathrm{w} / \mathrm{v})$. The most promising strain was selected for further studies.

\section{Identification of the potent feather degrading strain}

Phenotypic and biochemical properties of the isolate were investigated according to Cappuccino and Sherman (Cappuchino and Sherman 1999). The strain MBRL 575 was identified on the basis of $16 \mathrm{~S}$ rRNA gene sequence analysis. The 16S rRNA gene was amplified using the primers 8F (5-CAGAGTTTGATCCTGGCT-3) and 1522R 
(5-AGGAGGTGATCCAGCCGCA-3). The PCR mixture contained $25 \mu \mathrm{l} 2 \mathrm{X}$ Mastermix (Promega), $1 \mu \mathrm{l}$ of each primer $(20 \mathrm{mM})$ and the final volume was made up to $50 \mu \mathrm{l}$ with deionized water. PCR was carried out with initial denaturation at $94{ }^{\circ} \mathrm{C}$ for $5 \mathrm{~min}$ followed by 3 cycles of denaturation at $94{ }^{\circ} \mathrm{C}$ for $30 \mathrm{~s}$, annealing at $55^{\circ} \mathrm{C}$ for $30 \mathrm{~s}$, extension at $72{ }^{\circ} \mathrm{C}$ for $90 \mathrm{~s}$ and final extension at $72{ }^{\circ} \mathrm{C}$ for $10 \mathrm{~min}$. The amplified PCR product was detected by horizontal gel electrophoresis in $1 \%$ agarose gel at $100 \mathrm{~V}$ for 90 min using 1X TE buffer. The amplified 16S rRNA gene product was outsourced for sequencing at Xcelris Labs Ltd, India. The sequence obtained was then assembled and submitted to EzTaxon-e server database (Kim et al. 2012). The phylogenetic tree using neighbor-joining algorithm was constructed using MEGA 5 software package (Tamura et al. 2011).

\section{Inoculum preparation}

A loopful of bacterial culture was inoculated in Horikoshi-I broth and kept incubated under shaking conditions $\left(30{ }^{\circ} \mathrm{C}, 150 \mathrm{rpm}, 24 \mathrm{~h}\right)$. The culture broth was centrifuged $(10,000 \mathrm{rpm}, 30 \mathrm{~min})$. The pellet was collected, washed twice with sterile distilled water and then centrifuged. The pellet was then dissolved in $10 \mathrm{ml}$ sterile distilled water and optical density (OD) was measured at $600 \mathrm{~nm}$ and OD was adjusted to 0.5 .

\section{Source of chicken feather}

Feathers of 45 day old broiler chickens were collected from local slaughter houses, washed thoroughly with tap water, and dried in the oven. The dried feathers were cut into pieces $(2-3 \mathrm{~cm})$ and used for media preparation.

\section{Feather weight loss}

Feather weight loss was measured according to Bertsch and Coello (Bertsch and Coello $2005)$ with some modifications. The culture broth was filtered through a sieve $(1 \mathrm{~mm}$ mesh) and washed twice with distilled water. The residue was dried on a pre-weighed filter paper in an oven at $60^{\circ} \mathrm{C}$ until constant weight.

\section{Chicken feather degradation by MBRL 575}

Feather degradation was carried out in CFM. The medium was inoculated with $5 \%$ (v/v, $\left.0.5 \mathrm{OD}_{600}\right)$ inoculum. The inoculated flasks were kept incubated on a shaker $(150 \mathrm{rpm}$, $30{ }^{\circ} \mathrm{C}$ ). Time course of feather degradation was monitored by taking the fermentation broth at various time intervals and monitoring feather weight loss, keratinase, soluble peptide and amino acid production. The strain was also checked for its ability to degrade various bird feathers other than chicken feather by replacing chicken feather with other bird feathers. In order to investigate the effects of heat treatment of feather on keratinase, soluble peptide and amino acid production, chicken feather was autoclaved for different cycles (1, 2 and 3). In another case, feather was surface sterilized with isopropanol instead of autoclaving. Effect of feather concentration was monitored by adding feather at different concentrations. Effects of incubation temperature were also studied by growing MBRL 575 in CFM at different temperatures. For evaluating effects of carbon and nitrogen supplements on feather degradation, various carbon sources viz. glucose, sucrose, citrate, corn starch and lactose were added in CFM at $1 \%(\mathrm{w} / \mathrm{v})$ concentration 
and nitrogen sources viz. peptone, yeast extract, soybean meal, beef extract, $\mathrm{KNO}_{3}$ and $\mathrm{NH}_{4} \mathrm{Cl}$ were added at $0.5 \%(\mathrm{w} / \mathrm{v})$ concentration.

\section{Keratinase assay}

Keratinase activity was determined using keratin azure as substrate according to Sousa et al. (2007) with some modifications. $20 \mathrm{mg}$ keratin was suspended in $4 \mathrm{ml}$ of $50 \mathrm{mM}$ Glycine- $\mathrm{NaOH}$ buffer, $\mathrm{pH} 10.1 \mathrm{ml}$ of appropriately diluted enzyme was added and incubated at $55^{\circ} \mathrm{C}$ in a water bath for $1 \mathrm{~h}$. The reaction mixture was filtered through glass wool and absorbance was measured at $595 \mathrm{~nm}$. One unit of keratinolytic activity was defined as the amount of enzyme that led to an increase in absorbance of 0.01 at $595 \mathrm{~nm}$ under standard assay conditions.

\section{Determination of soluble peptides and amino acid concentration}

Soluble peptide content was determined according to Lowry method using bovine serum albumin (BSA) as standard (Lowry et al. 1951). Amino acid content was measured by ninhydrin method with L-leucine as standard (Lee and Takahashi 1966). In all the experiments, un-inoculated samples were included as controls and used as blanks. Absorbance was measured against the appropriate blank.

\section{Determination of free thiol group}

Free thiol group concentration was measured using Ellman reagent [DNTB (5,5'-dithio (2-nitrobenzoic acid)] with reduced glutathione as standard. $39.6 \mathrm{mg}$ DTNB was dissolved in $10 \mathrm{ml}$ phosphate buffer (100 mM, pH 7.2). To $3 \mathrm{ml}$ of appropriately diluted sample, $20 \mu \mathrm{l}$ DTNB solution was added. A blank sample (un-inoculated medium) was also included in the reaction. Then, the absorbance was measured at $412 \mathrm{~nm}$ after $2 \mathrm{~min}$ of stable colour development against the blank (Ellman 1959).

\section{Preparation of concentrated enzyme extract}

To $1.0 \mathrm{~L}$ enzyme extract, $390 \mathrm{~g}$ of anhydrous $\left(\mathrm{NH}_{4}\right)_{2} \mathrm{SO}_{4}$ was added (60\% saturation) and the mixture was centrifuged $(10,000 \mathrm{rpm}, 30 \mathrm{~min})$. The precipitate obtained was dissolved in a minimal volume of Glycine- $\mathrm{NaOH}$ buffer $(50 \mathrm{mM}, \mathrm{pH} 10)$ and dialyzed overnight against the same buffer at $4{ }^{\circ} \mathrm{C}$.

\section{Release of soluble peptides from native feather by cell free enzyme extract}

$1 \mathrm{~g}$ of non autoclaved and autoclaved chicken feathers ( 1 cycle autoclaved) were treated with $100 \mathrm{ml}$ of concentrated enzyme extract $(600 \mathrm{U} / \mathrm{ml})$ and incubated at $40{ }^{\circ} \mathrm{C}$. The reaction mixture was taken out at various time intervals and the enzyme was then inactivated by heating in boiling water bath. Then, the reaction mixture was filtered through a Whatman no. 1 filter paper and release of soluble peptides by keratinase enzyme was monitored.

\section{Evaluation of biocontrol activity}

The strain MBRL 575 was subjected to biocontrol assay against major rice fungal pathogens (Rhizoctonia solani and Rhizoctonia oryzae-sativa) on nutrient agar plates by dual culture technique. Colony growth inhibition was calculated using the formula: 
Percentage of colony growth inhibition $=[(\mathrm{C}-\mathrm{T}) / \mathrm{C}] \times 100$

where, $C$ represents the radial growth of the test pathogen in the control plates $(\mathrm{mm})$, and $\mathrm{T}$ is the radial growth of the test pathogen in the test plates (mm) (Hamdali et al. 2008).

\section{Scanning electron microscopy}

MBRL 575 grown in CFM and fermentation broth was filtered with Whatman No.3 filter paper after $0 \mathrm{~h}, 12 \mathrm{~h}$ and $24 \mathrm{~h}$ of incubation. The filtered feather was fixed with $2.5 \%$ (v/v) glutaraldehyde and $2 \%(\mathrm{v} / \mathrm{v})$ formalaldehyde for $24 \mathrm{~h}$. The specimens were dehydrated several times with $70-80 \%$ acetone and dried at $50{ }^{\circ} \mathrm{C}$ for $10 \mathrm{~min}$. The specimens were observed using FEI Quanta 250 scanning electron microscope (Rahayu et al. 2012).

\section{Statistical analysis of data}

All the above experiments were repeated in triplicate and the final values have been presented as mean \pm S.D.

\section{Results and discussion}

Isolation and identification of alkaliphilic bacterial strains

16 morphologically distinct bacterial strains were recovered from soil samples collected from limestone deposit sites. The isolates were investigated for possible degradation of chicken feather in CFM medium. 3 strains were found to degrade chicken feather. One isolate, MBRL 575, could degrade feather completely in $48 \mathrm{~h}$. However, the other two isolates (UAH-5 and UAH-7) took 4-5 days for complete degradation of feather. Hence, MBRL 575 was selected for further studies.

The strain MBRL 575 is a gram positive, endospore forming, rod shaped, motile bacterium. It showed positive results for catalase, oxidase, nitrate reduction, methyl red, gelatin liquefaction, and starch hydrolysis tests and negative for, Voges-Proskauer, Tween 20/80 hydrolysis and urease production tests. It could produce acid from glucose, fructose, sucrose, melibiose, mannitol, trehalose, mannose, lactose and inulin but not from glycerol and galactose. The organism forms opaque yellow colonies on Horikoshi Medium 1; colonies were regular in shape, moist and very sticky. It could grow at temperature range of $20-45^{\circ} \mathrm{C}$ and tolerate up to $15 \% \mathrm{NaCl}$. It grew at $\mathrm{pH} 7-12$ with an optimum $\mathrm{pH}$ of $9-10$. Based on morphological characterization and 16S rDNA sequence analysis, MBRL 575 was identified as a Bacillus sp. and designated as Bacillus sp. MBRL 575(NCBI GenBank Accession No. KC865830). It showed closest $16 \mathrm{~S}$ rRNA gene sequence similarities with Bacillus oshimensis (99.63\%), Bacillus lehensis (99.56 \%) and Bacillus hunanensis (99.34 \%). Nimaichand et al. (Nimaichand et al. 2015) have earlier reported isolation of actinobacteria from limestone deposit site at Hundung but this is the first report on isolation of alkaliphilic Bacillus species from this region. Analysis of phylogenetic tree indicated that MBRL 575 is not closely related with other feather degrading Bacillus spp. e.g. B. licheniformis (Xu et al. 2009), B.subtilis (Gupta and Singh 2014) B.cereus (Lakshmi et al. 2013), B.pumilus (Fakhfakh-Zouari et al. 2010), and B.altitudinis (Kumar et al. 2011) which have been reported earlier (Fig. 1). 


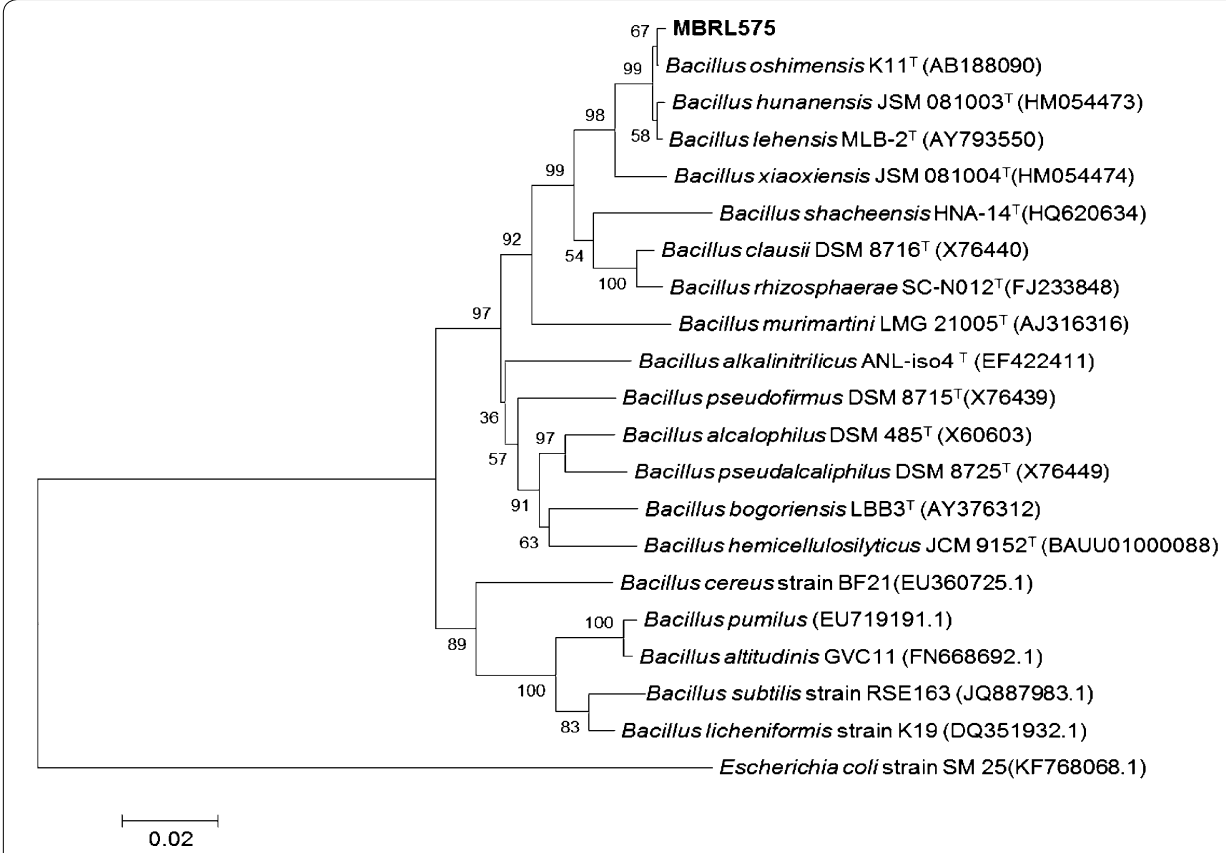

Fig. 1 Neighbour-joining tree based on 16S rRNA gene sequences, showing the relationships between strain MBRL 575 and other type strains of Bacillus species. Escherichia coli strain SM 25(KF768068.1) was used as the outgroup. Numbers at nodes are levels of bootstrap support (\%) for branch points (1000 resamplings). Bar 0.02 substitutions per nucleotide position

\section{Time course of feather degradation}

Degradation of chicken and other bird feathers by strain MBRL 575 are shown in Fig. 2. Degradation of feather barbules was apparent from $12 \mathrm{~h}$ of incubation onwards. However, complete degradation (98\% weight loss) was observed after $48 \mathrm{~h}$ at $30{ }^{\circ} \mathrm{C}$. According to a previous report by El-Refai et al. different Bacillus spp. showed different extents of feather degradation as indicated by feather weight loss viz. Bacillus pumilus FH9 (96 \%), Bacillus licheniformis SA1 (70.8 \%) and Bacillus subtilis (42.0 \%) when grown on basal medium supplemented with $1 \%$ chicken feathers after $48 \mathrm{~h}$ of incubation $37^{\circ} \mathrm{C}$ (El-Refai et al. 2005). Nagal and Jain reported that Bacillus cereus KB043 showed $78.16 \pm 0.4 \%$ weight loss after 6 days of incubation at $37^{\circ} \mathrm{C}$ (Nagal and Jain 2010). Park and Son reported complete degradation of chicken feather by Bacillus megaterium after 7 days (Park and Son 2009) and Williams et al. (1990) showed that Bacillus licheniformis PWD-1 degraded chicken feather completely after 10 days. In comparison to the feather degrading bacteria mentioned earlier, MBRL 575 is a relatively more efficient feather degrading strain. Scanning electron microscopic (SEM) observations revealed the colonization of bacteria on feather as well as disintegration of feather barbules after $12 \mathrm{~h}$ of incubation (Fig. 3b). After $24 \mathrm{~h}$ of incubation, the rachi and barbules were degraded and bacteria were found embedded in biomass of the degraded feathers (Fig. 3c). MBRL 575 produced $305 \pm 12 \mathrm{U} / \mathrm{ml}$ keratinase and could liberate $120 \pm 5.5 \mathrm{mg}$ of soluble peptides and $158 \pm 4 \mathrm{mg}$ of amino acids per gram of feather after $48 \mathrm{~h}$ of incubation (Figs. $4 \mathrm{a}, \mathrm{b}$ ). Laba and Rodziewicz reported that $2.1 \mathrm{mg} / \mathrm{ml}(210 \mathrm{mg} / \mathrm{g}$ of feather) of soluble protein 


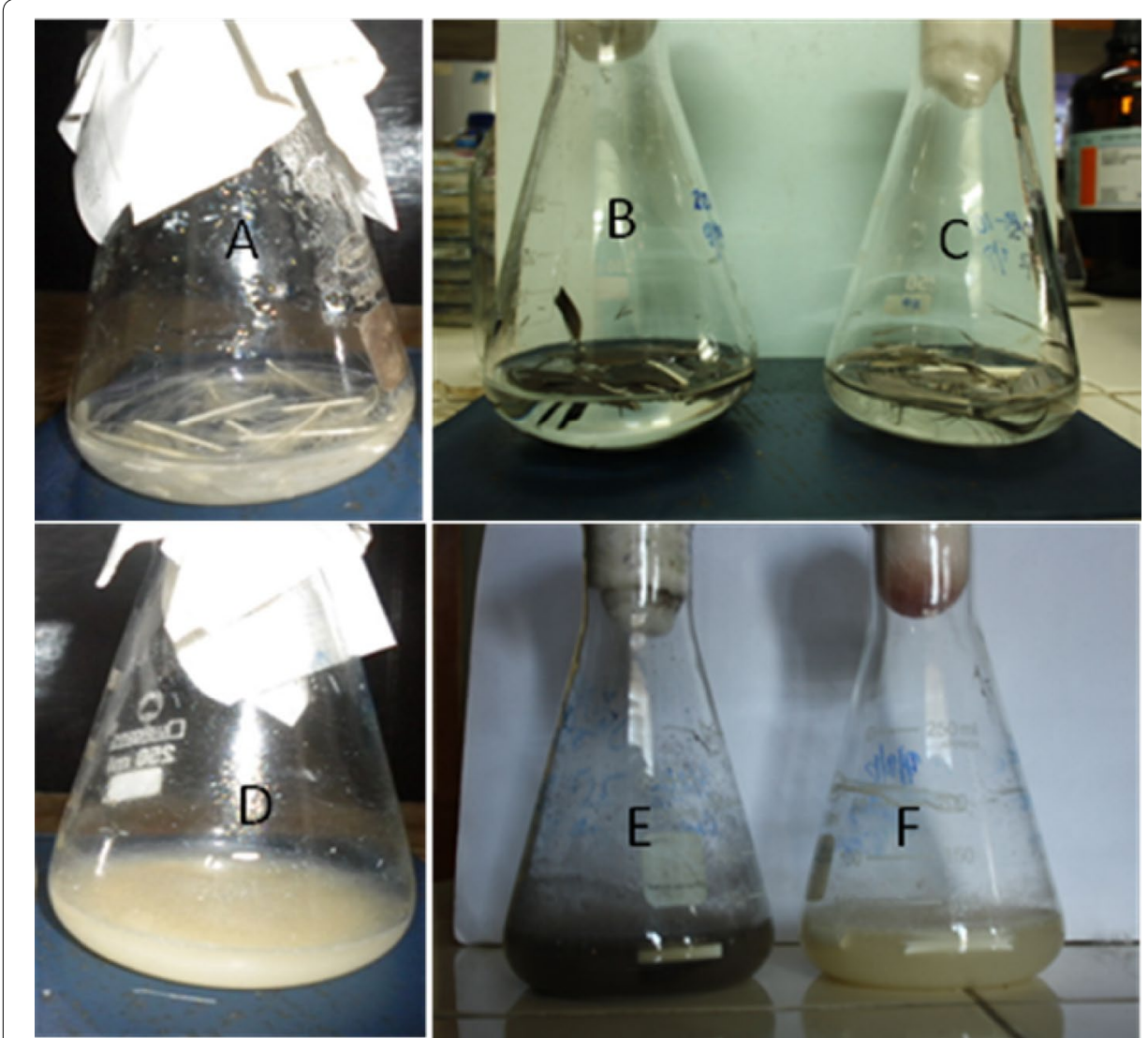

Fig. 2 Degradation of different bird feathers by Bacillus sp. MBRL 575 at 48 h, $30^{\circ} \mathrm{C}$. a Chicken feather (control), b duck feather (control), c Turkey feather (control), d chicken feather (48 h incubation), e duck feather (48 $\mathrm{h}$ incubation) $\mathbf{f}$ Turkey feather (48 $\mathrm{h}$ incubation)

was liberated by Bacillus polymyxa and $2.35 \mathrm{mg} / \mathrm{ml}$ (235 mg/g of feather) by Bacillus cereus after 10 days of incubation (Laba and Rodziewicz 2010). Production of soluble protein and amino acids during feather degradation by various bacterial species have been reported earlier viz. Bacillus subtilis (Jeong et al. 2010b; Zaghloul et al. 2011), Bacillus pumilus (Son et al. 2008), Stenotrophomonas maltophilia (Jeong et al. 2010c), and Chryseobacterium sp. kr 6 (Riffel et al. 2003). Feather degradation is always accompanied by release of soluble peptides and amino acids in the culture medium. The major fraction of soluble protein present in the culture broth comes from feather keratin while the rest is accounted for by secretion of enzyme/protein by the microbe. Some part of the solubilized feather keratin is converted to microbial biomass and some are hydrolyzed to amino acids by the action of proteases (Daroit et al. 2009). Hence, extent of release of soluble protein and amino acids varies from organism to organism.

\section{Degradation of different bird feathers}

MBRL 575 could degrade several other bird feathers other than chicken feather. Feather weight loss, keratinase, soluble peptide and amino acid production occurred in the decreasing order of pigeon $>$ broiler $>$ kuroiler $>$ duck $>$ turkey (Fig. 5a, b). Similar 


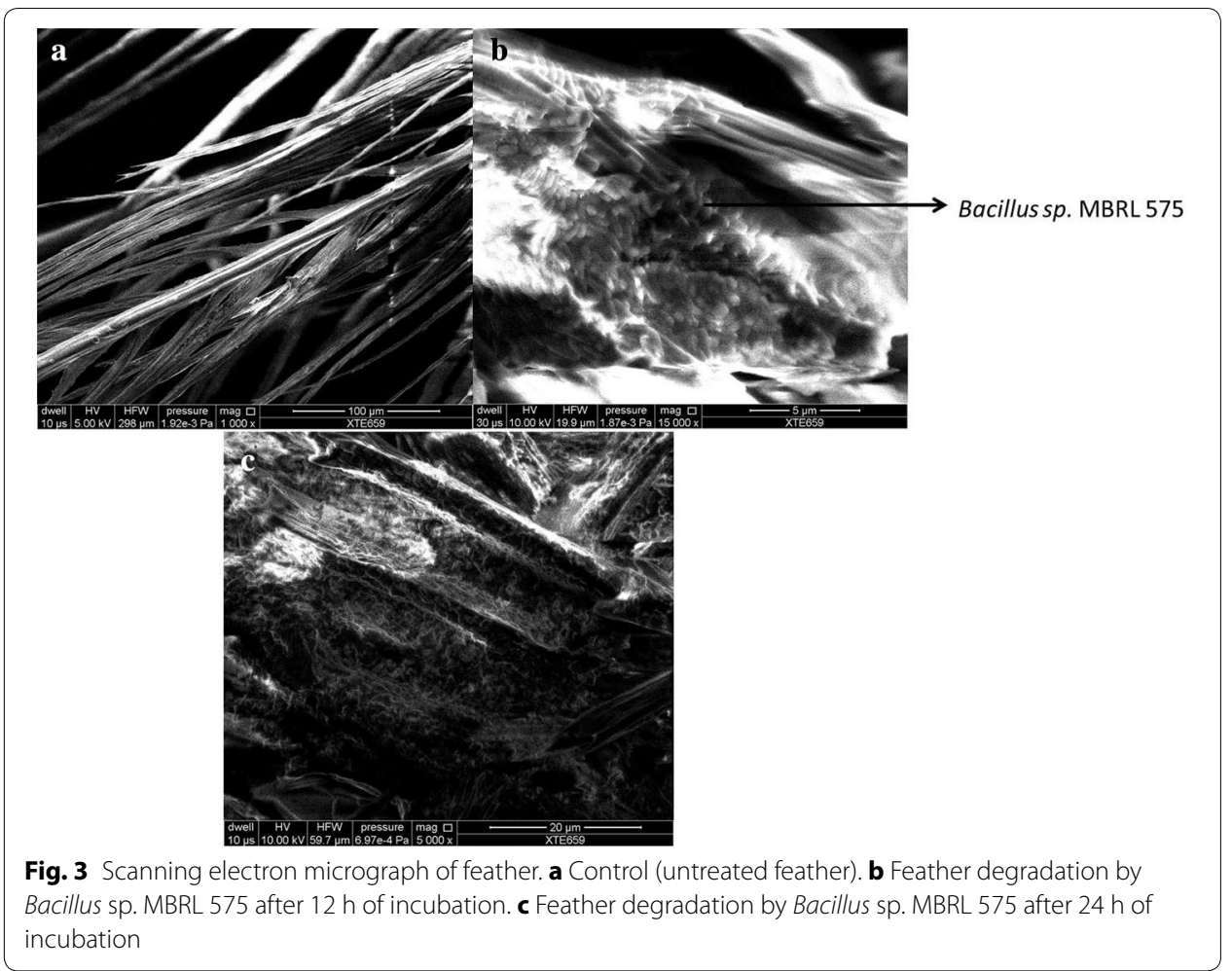

results were also reported by Saber et al. who observed chicken feather to be most efficiently degraded among various bird feathers (duck, goose, turkey) by two fungi Alternaria tenuissima and Aspergillus nidulans (Saber et al. 2009). MBRL 575 could degrade pigeon and broiler feather completely within $48 \mathrm{~h}$ of incubation. $84 \%$ feather weight loss was observed in kuroiler feather, $60 \%$ for duck feather and $40 \%$ for turkey feather. This showed that white feathers are more easily degraded than the coloured feathers. Resistance to bacterial degradation by coloured feathers may be attributed to presence of melanin pigment as observed by Gunderson et al. (2008). Efficient degradation of chicken feather by MBRL 575 is an important feature from bio-industrial point of view as chicken is most commonly consumed over other birds all over the world. Moreover, the ability of the organism to degrade different bird feathers may be a positive feature for bio-waste management.

\section{Effect of various factors on feather degradation}

As physiological and nutritional factors greatly affect feather degradation and keratinase production, the effects of various factors such as pretreatment of feather, feather concentration, incubation temperature and supplementary carbon and nitrogen sources on feather degradation by MBRL 575 were also studied and the results are summarized in Tables 1 and 2. Autoclaving of feather accelerated degradation of feather and production of keratinase, soluble peptides and amino acids. Only $46 \%$ feather weight loss was achieved by MBRL 575 in non-autoclaved feather as compared to $98 \%$ loss in autoclaved feather. Enhancement of feather degradation by autoclaving may be attributed to splitting of hydrogen bonds in keratin fibers by heating during autoclaving which make 

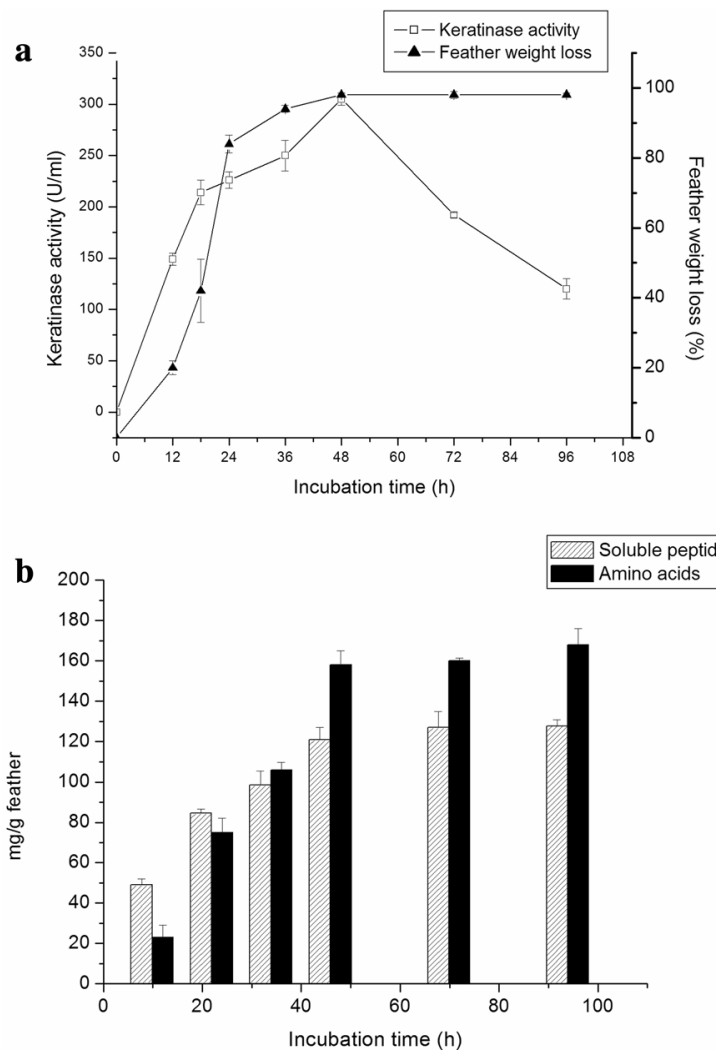

Fig. 4 Time course of feather degradation by MBRL 575. a Feather weight loss and keratinase production as a function time. MBRL 575 was grown in CFM and measured the keratinase activity and feather weight loss at $12 \mathrm{~h}$ time interval. Each point represents the mean of three independent experiments. $\mathbf{b}$ Release of soluble peptides and amino acids by MBRL 575 at $12 \mathrm{~h}$ time intervals. Cell-free supernatant was used for the measurement of soluble peptides by the Folin's method and amino acids by ninhydrin method. Each point represents the mean of three independent experiments

the keratin fibers more accessible to keratinase action. Similar results were also demonstrated by Szabo et al. who reported that heat sterilized feathers were digested more efficiently than $\gamma$ - ray or ethylene oxide sterilized feathers (Szabo et al. 2000). MBRL 575, interestingly, could degrade very high concentrations of feather after $48 \mathrm{~h}$ of incubation at $30{ }^{\circ} \mathrm{C}$. Even at $10 \%(\mathrm{w} / \mathrm{v})$ feather concentration, $40 \%$ of feather weight loss was achieved. Maximum keratinase production $(305 \pm 12 \mathrm{U} / \mathrm{ml})$ was observed at $1 \%$ feather concentration and further increase in feather concentration led to decreased keratinase production. Kainoor and Naik also observed that maximum keratinase production by Bacillus sp. JB 99 occurred at $1 \%$ feather concentration and further increase in feather concentration led to decreased enzyme production (Kainoor and Naik 2010). Cheng et al. 1995 also reported that higher concentration of feather powder decreased keratinase production by $B$. licheniformis PWD 1 . Soluble peptide and amino acid production by MBRL 575 increased as the feather concentration increased. However, release of soluble protein or amino acids per gram of feather was higher at lower feather concentrations and decreased as the feather concentration increased. Presence of high concentrations of feather in fermentation medium leads to drastic decrease in aeration and increase in viscosity which, in turn, retards microbial growth and keratinase production (Ramnani 

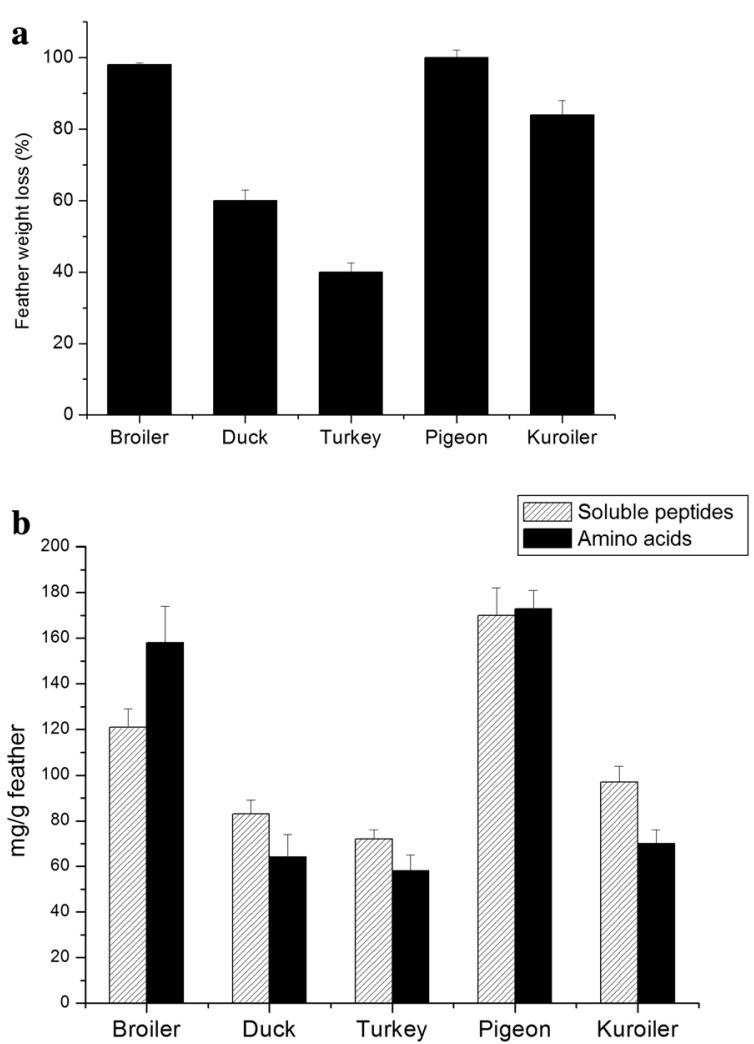

Fig. 5 Degradation of various bird feathers by MBRL 575. a Comparison of degradation of different bird feathers by Bacillus sp. MBRL 575 (feather weight loss). MBRL 575 was grown in medium containing $1 \%$ different feathers and kept incubated at $30^{\circ} \mathrm{C}, 150 \mathrm{rpm}$ for $48 \mathrm{~h}$. Each point represents the mean of three independent experiments. b Release of soluble peptides and amino acid production per gram of different bird feathers by Bacillus sp. MBRL 575 after $48 \mathrm{~h}$ of incubation. Each point represents the mean of three independent experiments

and Gupta 2004). Incubation temperature profoundly influenced keratinase production. Incubation temperature of $30^{\circ} \mathrm{C}$ resulted in maximal enzyme, soluble peptide and amino acid production. No feather degradation was observed at $40{ }^{\circ} \mathrm{C}$. Many keratinolytic bacteria such as B. megaterium F7-1, B. subtilis and Chryseoobacterium strain kr 6 showed optimum keratinase production at moderate temperatures (Park and Son 2009; Jeong et al. 2010b; Saber et al. 2009). Keratinolytic activity of mesophilic organisms may be an interesting property for biotechnological application as these microorganisms will be less energy consuming than the thermophilic ones for feather waste digestion (Jeong et al. 2010b).

\section{Effect of supplementary carbon (C) and nitrogen (N) sources}

Among the $\mathrm{C}$ sources tested, sodium citrate was found to be the best $\mathrm{C}$ supplement for keratinase production $(482 \pm 16 \mathrm{U} / \mathrm{ml})$ followed by glucose $(452 \pm 6 \mathrm{U} / \mathrm{ml})$, corn starch $(418 \pm 20 \mathrm{U} / \mathrm{ml})$ and sucrose $(394 \pm 14 \mathrm{U} / \mathrm{ml})$. Johnvesly and Naik (2001) also reported trisodium citrate and citric acid as good $\mathrm{C}$ sources for enhanced alkaline protease production. The use of these organic acids is interesting in view of their economy as well as their ability to control pH variation (Kumar and Takagi 1999). In contrast to our results, Kainoor and Naik reported that citric acid and other carbon sources led to 
Table 1 Effect of different factors on feather degradation by MBRL 575

\begin{tabular}{lcccc}
\hline Effect/treatment & $\begin{array}{l}\text { Feather } \\
\text { weight loss }(\%)\end{array}$ & $\begin{array}{l}\text { Keratinase } \\
\text { activity }(\mathbf{U} / \mathbf{m l})\end{array}$ & $\begin{array}{l}\text { Soluble peptides } \\
\text { (mg/g Feather) }\end{array}$ & $\begin{array}{l}\text { Amino acids } \\
\text { (mg/g feather) }\end{array}$ \\
\hline Temperature $\left({ }^{\circ} \mathrm{C}\right)$ & & & & \\
25 & $41 \pm 3.6$ & $80 \pm 2$ & $100 \pm 2.5$ & $109 \pm 3.6$ \\
28 & $79 \pm 3.6$ & $268 \pm 4.04$ & $111 \pm 3.05$ & $123 \pm 3.6$ \\
30 & $98 \pm 0.4$ & $305 \pm 12$ & $120 \pm 5.5$ & $158 \pm 4$ \\
35 & $48 \pm 2$ & $95 \pm 3.05$ & $102 \pm 6.1$ & $108 \pm 2$ \\
Feather concentration (w/v \%) & & & \\
0.5 & $100 \pm 0.5$ & $145 \pm 7$ & $161 \pm 3$ & $180 \pm 6$ \\
1.0 & $98 \pm 0.4$ & $305 \pm 12$ & $120 \pm 5.5$ & $158 \pm 4$ \\
2.0 & $85 \pm 1$ & $237 \pm 11$ & $110 \pm 2.6$ & $135 \pm 2.5$ \\
3.0 & $76 \pm 2$ & $139 \pm 7.7$ & $98 \pm 2$ & $116 \pm 3.05$ \\
5.0 & $61 \pm 2.5$ & $104 \pm 6.02$ & $80 \pm 2.5$ & $94.3 \pm 4.04$ \\
7.0 & $53 \pm 2.5$ & $77 \pm 7.5$ & $81 \pm 5.56$ & $94 \pm 3$ \\
10 & $45 \pm 3$ & $32 \pm 4$ & $81.3 \pm 6.4$ & $90 \pm 2$ \\
Pre-treatment of feather & & & & \\
Non-autoclaved & $46 \pm 4$ & $107 \pm 8$ & $58 \pm 8.2$ & $98 \pm 2$ \\
One cycle autoclaved & $98 \pm 0.5$ & $305 \pm 12$ & $120 \pm 5.5$ & $158 \pm 4$ \\
Two cycle autoclaved & $98 \pm 2$ & $310 \pm 10$ & $122 \pm 4$ & $162 \pm 6$ \\
Three cycle autoclaved & $99 \pm 3$ & $316 \pm 7$ & $126 \pm 6.2$ & $160 \pm 8.2$ \\
\hline
\end{tabular}

Table 2 Effect of carbon and nitrogen supplements on keratinase, soluble peptides and amino acid production

\begin{tabular}{lccc}
\hline & $\begin{array}{l}\text { Keratinase } \\
(\mathbf{U} / \mathbf{m l})\end{array}$ & $\begin{array}{l}\text { Soluble peptides } \\
(\mathbf{m g} / \mathbf{g} \text { feather })\end{array}$ & $\begin{array}{l}\text { Amino acids } \\
\text { (mg/g feather) }\end{array}$ \\
\hline $\begin{array}{l}\text { Carbon source }(1 \%, \mathrm{w} / \mathrm{v}) \\
\text { Control }\end{array}$ & & & \\
Glucose & $305 \pm 12$ & $120 \pm 5.5$ & $158 \pm 4$ \\
$\mathrm{Na}$ Citrate & $452 \pm 6$ & $136 \pm 7$ & $168 \pm 14$ \\
Corn starch & $482 \pm 16$ & $150 \pm 8.5$ & $227 \pm 18$ \\
Lactose & $418 \pm 20$ & $130 \pm 4$ & $176 \pm 8$ \\
Sucrose & $280 \pm 10$ & $88 \pm 6.2$ & $102 \pm 6.4$ \\
Nitrogen source $(0.5 \%, \mathrm{~W} / \mathrm{v})$ & $394 \pm 14$ & $129 \pm 12$ & $154 \pm 2.4$ \\
Peptone & $350 \pm 8$ & $130 \pm 6$ & $176 \pm 6$ \\
Yeast extract & $338 \pm 10$ & $107 \pm 16$ & $130 \pm 14$ \\
Soybean meal & $536 \pm 24$ & $164 \pm 10$ & $263 \pm 8$ \\
Beef extract & $362 \pm 6$ & $125 \pm 10.2$ & $54 \pm 6$ \\
$\mathrm{KNO}_{3}$ & $209 \pm 8$ & $115 \pm 8$ & $87 \pm 4$ \\
$\mathrm{NH}_{4} \mathrm{Cl}$ & $17 \pm 3$ & $52 \pm 4$ & \\
\hline
\end{tabular}

a Control represents CFM medium without any supplementary carbon or nitrogen source

decreased enzyme production by Bacillus sp. JB 99 (Kainoor and Naik 2010). Enhancement of keratinase production by glucose was also reported for Bacillus licheniformis ER-15 (Tiwary and Gupta 2010), Bacillus subtilis (Jeong et al. 2010b) and Bacillus megaterium F7-1 (Park and Son 2009). Addition of complex N sources such as soybean meal $(536 \pm 24 \mathrm{U} / \mathrm{ml})$, beef extract $(362 \pm 6 \mathrm{U} / \mathrm{ml})$, peptone $(350 \pm 8 \mathrm{U} / \mathrm{ml})$ and yeast extract (338 $\pm 10 \mathrm{U} / \mathrm{ml}$ ) enhanced keratinase production by MBRL 575 . Cheng et al. reported that supplementation of soybean meal enhanced keratinase production by $B$. 
licheniformis PWD 1(Cheng et al. 1995). In some organisms, soy flour was reported as good N supplement for keratinase production (Gradisar et al. 2005; Tiwary and Gupta 2010). However, inorganic nitrogen sources such as $\mathrm{KNO}_{3}$ and $\mathrm{NH}_{4} \mathrm{Cl}$ led to decreased enzyme production by MBRL 575. Similarly, Sahoo et al. (2012) reported inhibition of keratinase production by $\mathrm{NH}_{4} \mathrm{Cl}$ and $\mathrm{KNO}_{3}$. The inhibitory effect of inorganic salts on keratinase production may be attributed to the release of ammonia from these inorganic nitrogen sources (Uyar et al. 2011). Moreover, supplementation of $\mathrm{C}$ and organic $\mathrm{N}$ sources also enhanced production of soluble protein and amino acids by MBRL 575 .

\section{Determination of free thiol group}

Thiol formation increased during the exponential phase of microbial growth reaching maximum $(82 \mu \mathrm{M})$ at 3 days of incubation (Fig. 6). This coincides with the maximum enzyme production period. Microbial degradation of keratin is a complex process and one of the possible mechanisms for keratin degradation is the reduction of disulphide bonds. The mechanism of keratin degradation by strain MBRL 575 might also involve sulphitolysis as it produced free thiol group during keratin degradation. Similar reduction of disulfide bonds during feather degradation was also observed for Streptomyces pactum, Bacillus subtilis and Cryseobacterium sp. strain 6 (Bockel et al. 1995; Jeong et al. 2010b; Riffel et al. 2003).

\section{Feather degradation by cell free enzyme extract}

During fermentation soluble peptides and essential amino acids released from feather are utilized by the microorganism which decreases the nutritional value of feather meal (Tiwary and Gupta 2012). To circumvent this, research is now focused on use of keratinases rather than live microbial cells for feather meal preparation. Hence, the cell free enzyme extract of MBRL 575 was evaluated for feather degradation. The enzyme extract could release soluble peptides from native feathers (Fig. 7). Similarly, Vasela and Friedrich (2009) reported that crude keratinase from Paecilomyces marquandii

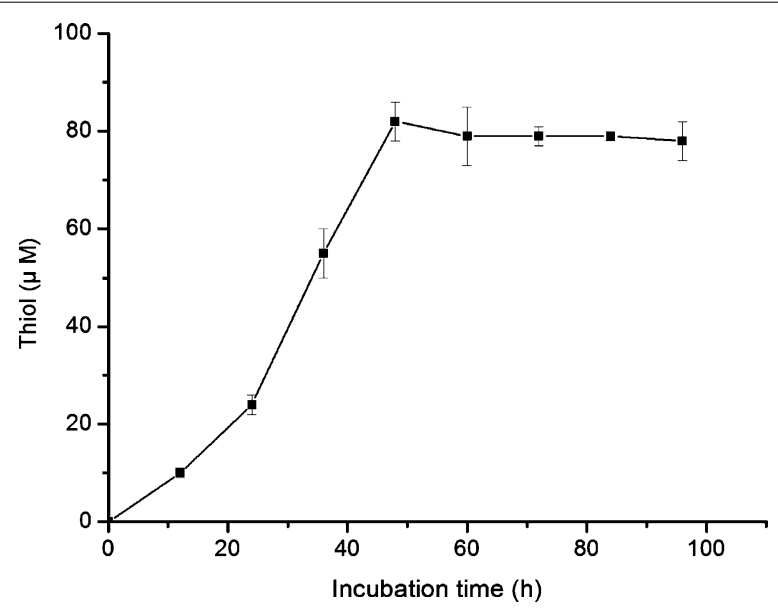

Fig. 6 Free thiol group released by MBRL 575. MBRL 575 was grown in CFM at $30^{\circ} \mathrm{C}, 150 \mathrm{rpm}$. Fermentation broth was collected at $12 \mathrm{~h}$ time interval and thiol production was measured using Ellman's reagent. Each point represents the mean of three independent experiments 


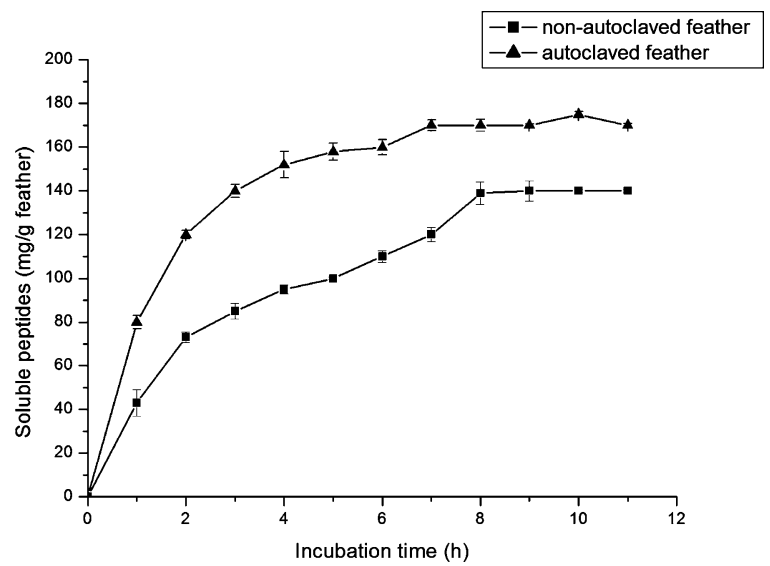

Fig. 7 Release of soluble peptides by cell free concentrated enzyme extract. $1 \mathrm{~g}$ feather was treated with $100 \mathrm{ml}$ (glycine- $\mathrm{NaOH}$ buffer $\mathrm{pH} 10)$ concentrated enzyme $(600 \mathrm{U} / \mathrm{ml})$ and kept incubated at $40^{\circ} \mathrm{C}$. Aliquots are taken out at $1 \mathrm{~h}$ time interval and measured release of soluble peptide using Folin's reagent. Each point represents the mean of three independent experiments

released soluble peptides from keratin substrates. In their case, release of soluble peptides increased till $4 \mathrm{~h}$ of incubation and remained constant. However, in our study release of soluble peptides increased till $7 \mathrm{~h}$ of incubation. Moreover, MBRL 575 keratinase could also degrade non-autoclaved chicken feathers. Soluble peptide release was higher in autoclaved ( $170 \mathrm{mg} / \mathrm{g}$ feather) feathers as compared to non-autoclaved feathers (140 $\mathrm{mg} / \mathrm{g}$ feather). In contrast, Park and Son reported that the cell free enzyme extract of Bacillus megaterium F7-1 could only degrade autoclaved feather and it could not degrade non autoclaved feather (Park and Son 2009).

\section{Evaluation of antagonistic activity against Rhizoctonia spp. by strain MBRL 575}

Besides efficient keratinolytic activity, the strain MBRL 575 showed antagonistic activity against major rice fungal pathogens, Rhizoctonia oryzae-sativae and Rhizoctonia solani, causing aggregate sheath spot disease and sheath blight respectively (Fig. 8). It showed more than $50 \%$ mycelial growth inhibition of both the indicator strains (Table 3). Some keratinolytic bacterial strains viz. Xanthomonas sp. P5, Bacillus subtilis and Stenotrophomonas maltophilia having antagonistic activity against phytopathogens have been previously reported (Jeong et al. 2010a, b; c).

\section{Conclusions}

A new feather degrading alkaliphilic bacterial strain, Bacillus sp. MBRL575, was isolated from a limestone habitat in Hundung, Manipur, India. The strain was an efficient feather degrader, achieving nearly complete degradation of broiler feather after $48 \mathrm{~h}$ of incubation. The organism produced significant amounts of enzyme, soluble peptides and amino acids in minimal medium containing chicken feather as the sole carbon and nitrogen source. There are meager reports of alkaliphilic Bacillus spp. that degrade feather. MBRL 575 is the first alkaliphilic Bacillus strain from limestone habitat with keratinolytic activity. None of the alkaliphilic Bacillus strains viz. B. oshimensis, B. lehensis and B. hunanensis, closely related to MBRL 575 has been reported to have feather degrading 

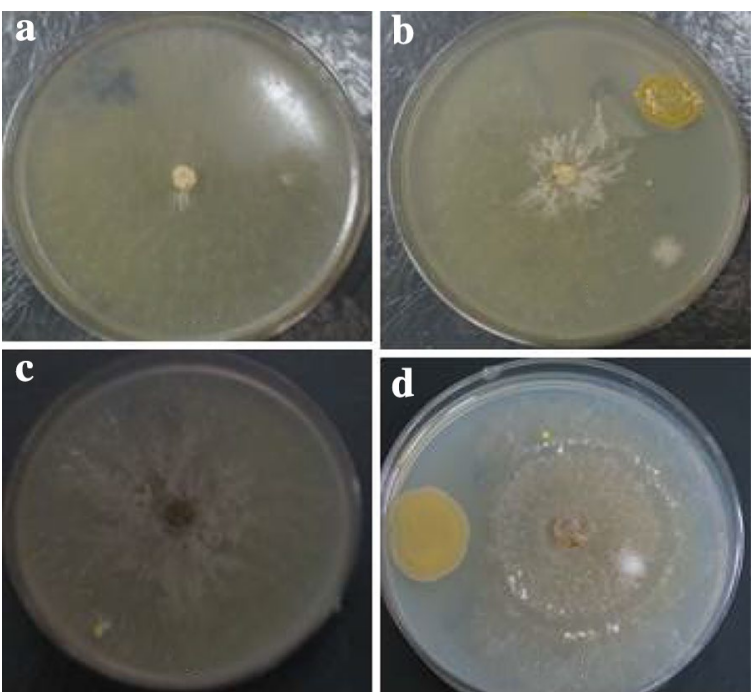

Fig. 8 Biocontrol activity of MBRL 575. a Rhizoctonia oryzae-sativae (control) b antagonistic activity against Rhizoctonia oryzae- sativae $\mathbf{c}$ Rhizoctonia solani (control) $\mathbf{d}$ antagonistic activity against Rhizzoctonia solani

Table 3 Antagonistic activity of MBRL 575 against Rhizoctonia spp

\begin{tabular}{ll}
\hline Fungal Pathogen & $\begin{array}{l}\text { \% of fungal mycelial } \\
\text { growth inhibition }\end{array}$ \\
\hline R. oryzae- sativae & 65 \\
R. solani & 58 \\
\hline
\end{tabular}

activity. Moreover, this strain did not show close phylogenetic affinities with other previously reported feather degrading Bacillus spp. The present study will add a new feather degrading alkaliphilic Bacillus sp. to the repertoire of keratinolytic bacteria. MBRL 575 and its keratinase are promising candidate agents for biotechnological application in feather waste bioremediation and valorization. In addition, the organism also exhibited antagonistic activities against two major rice pathogens: $R$. solani and $R$. oryzae-sativae. Further investigations will be needed to explore the potential of MBRL 575 as a biocontrol and/or biofertilizer agent.

\section{Authors' contributions}

PK did most of the work related to isolation, screening and feather degradation studies of MBRL 575 and wrote the initial Ms. DSN suggested the problem initially, supervised the work, edited the Ms, refined the discussion and suggested several more relevant references and interpreted the results and brought the revised Ms to the final form. All authors read and approved the final manuscript.

\section{Acknowledgements}

PK gratefully acknowledges the award of a research fellowship (CSIR-SRF) by Council of Scientific and Industrial Research (CSIR), Government of India, which facilitated the completion of this research work. The authors would also like to acknowledge the Research Instrumentation Facility, Manipur University, Canchipur for the SEM facility. We gratefully acknowledge the support of the State Biotech Hub Project, DBT, GOI (Grant No. BT/04/NE/2009) and Twinning Project, DBT, GOI (Grant No. BT/178/NE/TBP/2011) that facilitated this work.

\section{Competing interests}

The authors declare that they have no competing interests. 


\section{References}

Allpress JD, Mountain G, Gowland PC (2002) Production, purification and characterization of an extracellular keratinase from lysobacter NCIMB 9497. Lett Appl Microbiol 34:337-342

Bakhtiar S, Andersson MM, Gessesse A, Mattiasson B, Hatti-Kaul R (2002) Stability characteristics of a calcium-independent alkaline protease from Nesterenkonia sp. Enz Microb Tech 32:525-531

Bernal C, Cairo J, Coello N (2006) Purification and characterization of a novel exocellular keratinase from Kocuria rosea. Enz Microb Tech 38:49-54

Bertsch A, Coello N (2005) A biotechnological process for treatment and recycling poultry feathers as a feed ingredient. Bioresour Technol 96:1703-1708

Bockel B, Galunsky B, Muller R (1995) Characterization of a keratinolytic serine proteinase from Streptomyces pactum DSM 40530. Appl Environ Microbiol 61:3705-3710

Cao ZJ, Zhang Q, Wei DK, Chen JW, Zhang XQ, Zhou MH (2009) Characterization of a novel Stenotrophomonas isolate with high keratinase activity and purification of the enzyme. J Ind Microbiol Biotechnol 36:181-188

Cappuchino JG, Sherman N (1999) Microbiology: a laboratory manual, 4th edn. Addison-Wesley Longman Inc., England

Cheng SW, Hu HM, Shen SW, Takagi A, Asano M, Tsai YC (1995) Production and characterization of keratinase of a featherdegrading Bacillus licheniformis PWD-1. Biosci Biotechnol Biochem 59:2239-2243

Cheng X, Huang L, Tu XR, Li KT (2010) Medium optimization for the feather-degradation by Streptomyces fradiae var S-221 using the response surface methodology. Biodegradation 21:117-122

Chitte RR, Nalawade VK, Dey S (1999) Keratinolytic activity from the broth of a feather-degrading thermophilic Streptomyces thermoviolaceus strain SD8. Lett Appl Microbiolol 28:131-136

Daroit DJ, Correa AFF, Brandelli A (2009) Keratinolytic potential of a novel Bacillus sp. P45 isolated from the Amazon basin fish Piaractus mesopotamicus. Int Biodeter Biodegr 63:358-363

Ellman GL (1959) Tissue sulfhydryl groups. Arch Biochem Biophys 82:70-77

El-Refai HA, AbdelNaby MA, Gaballa A, El-Araby MH, Fatah AFA (2005) Improvement of the newly isolated Bacillus pumilus FH9 Keratinolytic activity. Process Biochem 40:2325-2332

Fakhfakh-Zouari N, Hmidet N, Haddar A, Kanoun S, Nasari M (2010) A novel serine metallokeratinase from a newly isolated Bacillus pumilus A1 grown on chicken feather meal: biochemical and molecular characterization. Appl Biochem Biotechnol 162:329-344

Fang Z, Zhang J, Liu B, Du G, Chen J (2013) Biodegradation of wool waste and keratinase production in scale-up fermenter with different strategies by Stenotrophomonas maltophilia BBE11-1. Bioresour Technol 143:186-291

Friedrich AB, Antranikian G (1996) Keratin degradation by Fervidobacterium pennavorans, a novel thermophilic anaerobic species of the order thermotogales. Appl Environ Microbiol 62:2875-2882

Gradisar H, Friedrich J, Krizaj I, Jerala R (2005) Similarities and specificities of fungal keratinolytic proteases: comparison of keratinases of Paecilomyces marquandii and Doratomyces microspores to some known proteases. Appl Environ Microbiol 71(7):3420-3426

Grazziotin A, Pimentel FA, Sangali S, Jeong EVD, Brandelli A (2007) Production of feather protein hydrolysate by keratinolytic bacterium Vibrio sp. Kr 2. Bioresour Technol 98:3172-3175

Gunderson AR, Frame AM, Swaddle JP, Forsyth MH (2008) Resistance of melanised feathers to bacterial degradation: is it really so black and white. J Avian Biol 39:539-545

Gupta R, Ramnani P (2006) Microbial keratinases and their prospective applications: an overview. Appl Microbiol Biotechnol 70:21-33

Gupta S, Singh R (2014) Hydrolyzing proficiency of keratinases in feather degradation. Indian J Microbiol 54:466-470

Hamdali H, Hafidi M, Virolle MJ, Ouhdouch Y (2008) Isolation and characterization of rock phosphate solubilisation actinobacteria from Togolese phosphate mine. World J Microbiol Biotechnol 24:2565-2575

Horikoshi K (2004) Alkaliphiles. Proc Jpn Acad Ser B 80:166-178

Jayalakshmi T, Krishnamoorthy P, Kumar GR, Sivamani P, Lakshmi CGA (2012) Application of pure keratinase on keratinous fibers to identify the keratinolytic activity. J Chem Pharm Res 4(6):3229-3233

Jeong JH, ParK KH, Oh DJ, Hwang DY, Kim HS, Lee CY, Son HJ (2010a) Keratinolytic enzyme-mediated biodegradation of recalcitrant feather by a newly isolated Xanthomonas sp. P5. Polym Degrad Stab 95:1969-1977

Jeong JH, Jeon YD, Lee OM, Kim JD, Lee NR, Park GT, Son HJ (2010b) Characterization of a multifunctional feather-degrading Bacillus subtilis isolated from forest soil. Biodegradation 21:1029-1040

Jeong JH, Lee OM, Jeon YD, Kim JD, Lee NR (2010c) Production of keratinolytic enzyme by a newly isolated featherdegrading Stenotrophomonas maltophilia that produces plant growth-promoting activity. Process Biochem 45:1738-1745

Johnvesly B, Naik GR (2001) Studies on production of thermostable alkaline protease from thermophilic and alkaliphilic Bacillus sp. JB-99 in a chemically defined medium. Proc Biochem 37:139-144

Kainoor PS, Naik GR (2010) Production and characterization of feather degrading keratinase from Bacillus sp. JB 99. Ind J Biotechnol 9:384-390

Kim OS, Cho YJ, Lee K, Yoon SH, Kim M, Na H, Park SC, Jean YS, Lee JH, Yi H, Won S, Chun J (2012) Introducing EZ Taxon-e: a prokaryotic 16S rRNA gene sequence database with phylotypes that represent uncultural species. Int I Syst Evol Microbiol 62:716-721

Kumar CG, Takagi H (1999) Microbial alkaline protease: from a bioindustrial viewpoint. Biotechnol Adv 17:561-594

Kumar EV, Srijana M, Chaitanya K, Harish Y, Reddy K, Reddy G (2011) Biodegradation of poultry feathers by a novel bacterial isolate Bacillus altitudinis GVC11. Indian J Biotechnol 10:502-507

Laba W, Rodziewicz A (2010) Keratinolytic potential of feather-degrading Bacillus polymyxa and Bacillus cereus. Pol J Environ Stud 19:371-378

Lakshmi PJ, Chitturi CMK, Lakshmi VV (2013) Efficient degradation of feather by keratinase producing Bacillus sp. Int J Microbiol. doi:10.1155/2013/608321

Langeveld JPM, Wang JJ, Van-de-Wiel DFM, Shih GC, Garssen GJ, Bossers A, Shih JCH (2003) Enzymatic degradation of prion protein in brain stem from infected cattle and sheep. J Infect Dis 188:1782-1789 
Lee YP, Takahashi T (1966) An improved colorimetric determination of amino acids with the use of ninhydrin. Anal Biochem 14:71-77

Letourneau F, Soussotte V, Branland P, Verneuil B (1998) Keratinolytic activity of Streptomyces sp. S.K K1-20. Lett Appl Microbiol 26:77-80

Lowry OH, Rosebrough NJ, Farr AL, Randall RJ (1951) Protein measurement with the folin phenol reagent. J Biol Chem 193:267-275

Nagal S, Jain PC (2010) Feather degradation by strains of Bacillus isolated from decomposing feathers. Braz J Microbiol 41:196-200

Nam GW, Lee DW, Lee HS, Lee NJ, Kim BC, Choe EA, Hwang JK, Suhartono MT, Pyun YR (2002) Native-feather degradation by Fervidobacterium islandicum AW-1, a newly isolated keratinase-producing thermophilic anaerobe. Arch Microbiol 178:251-263

Nimaichand S, Devi AM, Tamreihao K, Ningthoujam DS, Li WJ (2015) Actinobacterial diversity in limestone deposit sites in Hundung, Manipur (India) and their antimicrobial activities. Front Microbiol. doi:10.3389/fmicb.2015.00413

Park GT, Son HJ (2009) Keratinolytic activity of Bacillus megaterium F7-1, a feather-degrading mesophilic bacterium. Microbiol Res 164:478-485

Rahayu S, Syah D, Suhartono T (2012) Degradation of keratin by keratinase and disulfide reductase from Bacillus sp. MTS of Indonesian origin. Biocat Agric Biotechnol 1:152-158

Ramnani P, Gupta R (2004) Optimization of medium composition for keratinase production on feather by Bacillus licheniformis RG1 using stastical methods involving response surface methodology. Biotechnol Appl Biochem 40:191-196

Riffel A, Lucas F, Heeb P, Brandelli A (2003) Characterization of a new keratinolytic bacterium that completely degrades native feather keratin. Arch Microbiol 179:258-265

Riffel A, Brandelli A, Bellato CM, Souza GHMF, Eberlin MN, Tavares FCA (2007) Purification and characterization of a keratinolytic metalloprotease from Chryseobacterium sp. Kr 6. J Biotechnol 128:693-703

Saber WIA, El-Metwally MM, El-Hersh MS (2009) Keratinase production and biodegradation of some keratinous wastes by Alternaria tenuissima and Aspergillus nidulans. Res J Microbiol 5:21-35

Sahoo DK, Das A, Thatoi H, Mondal C, Mohapatra PKD (2012) Keratinase production and biodegradation of whole chicken feather keratin by a newly isolated bacterium under submerged fermentation. Appl Biochem Biotechnol 167:1040-1051

Sangali S, Brandelli A (2000) Feather keratin hydrolysis by a Vibrio sp. strain kr 2. J Appl Microbiol 89:735-743

Sharma R, Gupta R (2010) Thermostable thiol activated keratinase from Pseudomonas aeruginosa KS-1 for prospective application in prion decontamination. Res J Microbiol 5:954-965

Son HJ, Park HC, Kim HS, Lee CY (2008) Nutritional regulation of keratinolytic activity in Bacillus pumilus. Biotechnol Lett 30:461-465

Sousa F, Jus S, Erbel A, Kokol V, Cavaco-Paulo A, Gubtiz GM (2007) A novel metalloprotease from Bacillus cereus for protein fiber processing. Enz Microbial Technol 40:1772-1781

Szabo I, Benedek A, Szabo IM, Barabas G (2000) Feather degradation with a thermotolerant Streptomyces graminofaciens strain. World J Microbiol Biotechnol 16:253-255

Takami H, Nakumura S, Ano R, Horikoshi K (1992) Degradation of human hair by a thermostable alkaline protease from alkaliphilic Bacillus sp. no AH-101. Biosci Biotechnol Biochem 56:1667-1669

Tamura K, Peterson D, Stecher G, Nei M, Kumar S (2011) MEGA5: Molecular evolutionary genetics analysis using maximum likelihood, evolutionary distance and maximum parsimony and methods. Mol Biol Evol 28:2731-2739

Thys RC, Brandelli A (2006) Purification and properties of a keratinolytic metalloprotease from Microbacterium sp. J App Microbiol 101:1259-1268

Tiwary E, Gupta R (2010) Medium optimization for a novel 58 kDa dimeric keratinase from Bacillus licheniformis ER-15: biochemical characterization and application in feather degradation and dehairing of hides. Bioresour Technol 101:6103-6110

Tiwary E, Gupta R (2012) Rapid conversion of chicken feather to feather meal using dimeric keratinase from Bacillus licheniformis ER-15. J Bioprocess Biotech 4:1-5

Tork S, Aly MM, Nawar L (2010) Biochemical and molecular characterization of a new local keratinase producing Pseudomonas sp. MS 21. Asian J Biotechnol 23:295-299

Uyar F, Porsuk I, Kizil G, Yilmaz El (2011) Optimal conditions for production of extracellular protease from newly isolated Bacillus cereus strain CA 15. Eurasia J BioSci 5:1-9

Vasela M, Friedrich J (2009) Amino acid and soluble protein cocktail from waste keratin hydrolyzed by a fungal keratinase of Paecilomyces marquandii. Biotechnol Bioprocess Eng 14:84-90

Vidal L, Christe P. Coello MN (2000) Feather degradation by Kocuria rosea in submerged culture. World J Microbiol Biotechnol 16:551-554

Wang SL, Hsu WT, Liang TW, Yen YH, Wang CL (2008) Purification and characterization of three novel keratinolytic metalloproteases produced by Chryseobacterium indologenes TKU014 in shrimp shell powder medium. Bioresour Technol 99:5679-5686

Williams CM, Richter CS, Mackenzie JMJR, Shih JCH (1990) Isolation identification and characterization of a feather degrading bacterium. Appl Environ Microbiol 56:1509-1515

Xu B, Zhong Q, Tang X, Yang Y, Huang Z (2009) Isolation and characterization of a new keratinolytic bacterium that exhibits significant feather-degrading capability. Afr J Biotechnol 8(18):4590-4596

Zaghloul TI, Embaby AM, Elmahdy AR (2011a) Key determinants affecting sheep wool biodegradation directed by a keratinase-producing Bacillus subtilis recombinant strain. Biodegradation 22:111-128

Zaghloul TI, Embaby AM, Elmahdy AR (2011b) Biodegradation of chicken feather waste directed by Bacillus subtilis recombinant cells: scaling up in a laboratory scale fermentor. Bioresour Technol 102:2387-2393 